Katarzyna Błaszczuk

Uniwersytet Rzeszowski
Kiedy myślimy Rodzina..., red. M. Duda,

K. Kutek-Sładek, Kraków 2016, s. 141-159

(Praca Socjalna w Teorii i Działaniu, 2).

\title{
Pułapka współuzależnienia w rodzinie z problemem alkoholowym
}

\author{
The trap of co-dependency in a family \\ with a drinking problem
}

\begin{abstract}
A family faced with alcohol dependence of its member most often does not take any action to solve the problem. This is mainly due to the lack of knowledge about co-dependency of all people living under one roof with the addict. The spouse/partner as well as children of the addicted individual feel shame as they are blamed by the person abusing alcohol for the situation, and that hinders or cripples any attempts to solve the problem. Times of drinking and associated fighting, aggression and violence are interspersed with "honeymoon-like periods", so family members are convinced that one day the addiction will end and "things will somehow turn out right". It is not only the drinking person but also his/her closest relatives who deny there is a problem if the fact is pointed out and confirmed by anyone outside the family. Despite the suffering and damage caused
\end{abstract}

by the lack of the drinking person's concern for his/her family as well as his/her absence and disengagement from the daily routines, the spouse/partner and the children put on "masks" and claim there is no problem. The greatest tragedy of children living in a family with a drinking problem is the fact that, without being aware of it, they continue to play the same roles in their adult life, as ACA. An addicted person may decide to stop drinking only if they admit full responsibility for the effects of their own lack of control over drinking which leads to significant damage on a personal and family level, exposing everyone to suffering and harm. Of great importance in motivating an alcoholic to remain sober is a short family intervention during a meeting in a group of people significant for the addict. The essence of co-dependency may be explained using 
a case study showing the attempts made by a wife trying to justify behaviours of her husband who abuses alcohol.
Keywords: addiction co-dependency

ACA crisis intervention

Uzależnienie od alkoholu przynajmniej jednego członka rodziny stanowi zagrożenie dla stabilności systemu rodzinnego. Rodzic nadużywający alkoholu nie potrafi zapewnić dzieciom bezpieczeństwa socjalnego ani zaspokoić potrzeb emocjonalnych, ponieważ priorytetem jest dla niego zdobycie środków na alkohol. Drugi rodzic, odczuwając wstyd i poczucie winy za pijącego, nieświadomie zwalnia go z odpowiedzialności za wszystkie problemy rodziny oraz ponoszone koszty ekonomiczne i społeczne związane z postawą nadużywającego alkoholu. Niepijący rodzic pragnie ukrywać problem i własne cierpienie przed dziećmi i najbliższym otoczeniem, nie zdając sobie sprawy z tego, że niepodejmowanie żadnych działań w kierunku naprawy sytuacji oznacza współuczestniczenie w umacnianiu dysfunkcyjnego systemu rodzinnego.

Określenie współuzależnienia w tytule opracowania jako „pułapki” jest uzasadnione, ponieważ wszyscy członkowie rodziny z problemem alkoholowym są wplątywani przez osobę pijącą w sieć problemów utrudniających zaspokajanie potrzeb i funkcjonowanie w środowisku społecznym. Ponadto dzieci powielają w swoim dorosłym życiu pewne modele zachowań (charakterystyczne role), które pozwalały im przetrwać w chorym systemie rodzinnym w dzieciństwie. Wypaczone wzorce rodzica pijącego i współuzależnionego tworzą w przekonaniu dziecka model rodziny, w której każdy może liczyć wyłącznie na siebie, zaś dzieci nie powinny nikogo informować o problemach rodziny, aby nie przysparzać cierpień rodzicom, a siebie nie narażać na ryzyko wykluczenia społecznego lub umieszczenie w placówce opiekuńczo-wychowawczej. Przedstawione w artykule przykłady rodzin z problemem alkoholowym ukazują sytuacje transkryzysowe związane z postawami osób uzależnionych i współuzależnionych.

\section{Uzależnienie od alkoholu - wiedza i postawy}

Rodzina jest grupą ludzi zależnych od siebie w zaspokajaniu potrzeb uczuciowych, społecznych i duchowych. Jeżeli choć jeden członek rodziny jest uzależniony od alkoholu, wszystkich pozostałych dotykają problemy życiowe, finansowe i uczuciowe. Pomimo doświadczania cierpień i ponoszenia strat układ rodzinny pozostaje spójny ze względu na podporządkowanie życia rodziny osobie pijącej i chronienie jej przed emocjonalnymi i społecznymi skutkami 
nałogu. Każdego członka rodziny określa się mianem „osoby z problemem alkoholowym”, dlatego mówimy o „rodzinie z problemem alkoholowym”'.

Jeśli nawet osoby te same są abstynentami lub stają się przeciwnikami picia alkoholu, nie mogą pozbyć się problemu, ponieważ „wiele przeżyć, planów i życiowych rozwiązań kręci się wokół alkoholu, [dlatego] coraz częściej interwencje w leczeniu alkoholizmu rozpoczyna się od nieuzależnionych członków rodziny, uwikłanych przecież tak lub inaczej w problem alkoholowy"2.

Alkohol należy do substancji psychoaktywnych towarzyszących człowiekowi od początku jego historii na ziemi. Panuje powszechne przyzwolenie na picie alkoholu, z wyjątkiem ograniczeń dotyczących wieku osób pijących oraz kobiet w ciąży (od momentu udowodnienia szkodliwego wpływu na rozwój dziecka picia alkoholu przez kobietę ciężarną, bez względu na dawkę i częstotliwość jego przyjmowania). Samo spożywanie alkoholu przez osoby wolne od ograniczeń prawnych nie jest zabronione, jednak utrata kontroli nad piciem pociąga za sobą wiele konsekwencji z powodu „kryzysu nałogu”3. Przyczyny tego kryzysu przedstawia tabela 1 .

Tabela 1. Przyczyny kryzysu nałogu

\begin{tabular}{|c|l|l|}
\hline Lp. & \multicolumn{1}{|c|}{ Przyczyna } & \multicolumn{1}{c|}{ Charakterystyka } \\
\hline 1 & czas trwania & $\begin{array}{l}\text { - najdłuższy rodowód alkoholu spośród substancji psycho- } \\
\text { aktywnych } \\
\text { - wiele wysiłków legislacyjnych w celu promowania alkoholu } \\
\text { i kontrolowania jego spożycia }\end{array}$ \\
\hline 2 & $\begin{array}{l}\text { legalność } \\
\text { - niewiele jest okoliczności, w których posiadanie lub uży- } \\
\text { wanie alkoholu może zakończyć się wyrokiem pozbawienia } \\
\text { wolności } \\
\text { - społeczne przyzwolenie na jazdę po pijanemu i posiadanie } \\
\text { alkoholu przez osoby nieletnie ma znaczny wpływ na wymie- } \\
\text { rzanie kar }\end{array}$ \\
\hline 3 & $\begin{array}{l}\text { powszechność } \\
\text { używania }\end{array}$ & $\begin{array}{l}\text { - bardzo częstym tematem poruszanym przez media jest za- } \\
\text { żwanie innych substancji psychoaktywnych, jednak liczba } \\
\text { osób je przyjmujących jest niewspółmiernie mała w porówna- } \\
\text { niu z nadużywaniem alkoholu }\end{array}$ \\
\hline $\begin{array}{l}\text { nośrednie koszty } \\
\text { finansowe }\end{array}$ & $\begin{array}{l}\text { - utrata pracy } \\
- \text { przemoc domowa i rozwody } \\
- \text { leczenie szpitalne } \\
- \text { działania organów ścigania, wymiaru sprawiedliwości i sys- } \\
\text { temu więziennictwa }\end{array}$ \\
\hline
\end{tabular}

W. Sztander, Poza kontrolą, Warszawa 1997, s. 28-29.

Tamże.

3 R. K. James, B. E. Gilliland, Strategie interwencji kryzysowej, Warszawa 2004, s. 426. 


\begin{tabular}{|c|c|c|}
\hline Lp. & Przyczyna & Charakterystyka \\
\hline 5 & koszty psychiczne & $\begin{array}{l}\text { - problem współuzależnienia i funkcjonowania rodzin } \\
\text { - zjawisko przemocy fizycznej i seksualnej } \\
\text { - skomplikowana sytuacja dzieci w rodzinach z problemem } \\
\text { alkoholowym }\end{array}$ \\
\hline 6 & koszty fizyczne & $\begin{array}{l}\text { - urazy } \\
\text { - schorzenia wątroby i trzustki } \\
\text { - zespół Korsakowa } \\
\text { - zaburzenia funkcji seksualnych i rozrodczych } \\
\text { - nowotwory } \\
\text { - choroby serca } \\
\text { - zaniki kostne } \\
\text { - problemy żołądkowo-jelitowe } \\
\text { - obniżona odporność } \\
\text { - niedożywienie } \\
\text { - alkoholowy zespół płodowy } \\
\text { - zgony }\end{array}$ \\
\hline 7 & $\begin{array}{l}\text { związki } \\
\text { z przestępczością }\end{array}$ & $\begin{array}{l}\text { - napady } \\
\text { - morderstwa }\end{array}$ \\
\hline 8 & $\begin{array}{l}\text { udział } \\
\text { w nieszczęśliwych } \\
\text { wypadkach }\end{array}$ & $\begin{array}{l}\text { - zgony w wypadkach drogowych } \\
\text { - wypadki związane z wykonywaniem pod wpływem alko- } \\
\text { holu takich czynności, jak np. pływanie, przechodzenie przez } \\
\text { ulicę, naprawy w domu, upadekze schodów, polowanie, pale- } \\
\text { nie papierosa w łóżku }\end{array}$ \\
\hline 9 & samobójstwo & $\begin{array}{l}\text { - ryzyko popełnienia samobójstwa wśród alkoholików wy- } \\
\text { nosi ok. } 15 \%\end{array}$ \\
\hline 10 & $\begin{array}{l}\text { alkohol jest } \\
\text { narkotykiem }\end{array}$ & $\begin{array}{l}\text { - z powodu możliwości nabycia alkoholu legalnie ludzie za- } \\
\text { pominają, że jest to środek uzależniający } \\
\text { - arbitralny pogląd kulturowy nie definiuje osoby pijącej jed- } \\
\text { no piwo jako narkomana (osoba paląca jednego skręta mari- } \\
\text { huany jest tak określana) }\end{array}$ \\
\hline 11 & $\begin{array}{l}\text { używanie wielu } \\
\text { substancji }\end{array}$ & $\begin{array}{l}\text { - coraz częściej osoby pijące alkohol nadużywają wielu sub- } \\
\text { stancji psychoaktywnych, które popijają alkoholem, aby osią- } \\
\text { gnąć skumulowany efekt tanim kosztem }\end{array}$ \\
\hline 12 & $\begin{array}{l}\text { uwikłanie } \\
\text { w kontrowersje }\end{array}$ & $\begin{array}{l}\text { - stawiane jest pytanie, czy alkoholizm jest chorobą biologicz- } \\
\text { ną, czy chorobą woli } \\
\text { - przekonania dotyczące alkoholu są zakorzenione w kulturze } \\
\text { - powstało wiele modeli próbujących wyjaśnić źródła alkoho- } \\
\text { lizmu i określić sposoby jego leczenia* }\end{array}$ \\
\hline
\end{tabular}

* Richard K. James i Burl E. Gilliland wymieniają 16 modeli uzależnienia: behawioralnego uczenia się, biopsychospołeczny, poznawcze, choroby, drogi wjazdowej, predyspozycji genetycznej, stylu życia, wpływu rodzicielskiego, małych grup rówieśniczych, receptariuszowy, zachowań problemowych, psychoanalityczny, psychospołeczny, używania sankcjonowanego, socjokulturowe, radzenia sobie ze stresem. Jeśli chodzi o przydatność w leczeniu, żaden z tych modeli nie ma zdecydowanej przewagi, zob. R. K. James, B. E. Gilliland, Strategie..., dz. cyt., s. 428-430.

Źródło: R. K. James, B. E. Gilliland, Strategie interwencji kryzysowej, Warszawa 2004, s. 426427. Opracowanie własne. 
Kazimierz W. Frieske uważa, że odpowiedź na pytanie o postrzeganie pijaństwa w społeczeństwie można rozpoczynać od tezy ogłoszonej przez Stefana Nowaka, metodologa nauk społecznych, która brzmiała: „ludzkie wyobrażenia, przekonania, wartości, dążenia, motywy itp. są na tyle ważnymi czynnikami wyznaczającymi ludzkie działania, iż w analizie tych działań na tej subiektywno-wyobrażeniowej ich stronie należy przede wszystkim skupić uwagę" ${ }^{\text {. Autor }}$ odwołuje się również do debaty, która toczyła się w drugiej połowie XX wieku, na temat postaw ludzi wobec problemów społecznych i miejsca, jakie wśród nich zajmuje alkoholizm. „Otóż warto to wiedzieć, ponieważ w demokratycznym społeczeństwie uznaje się zwykle, że poglądy opinii publicznej legitymizują - przynajmniej w jakimś stopniu - alokacyjne decyzje władzy politycznej i rozmaite programy zorganizowanej, społecznej reakcji na te czy inne zjawiska; obserwacja dynamiki definiowania i identyfikacji problemów społecznych oraz ich instytucjonalizacji niesie ze sobą informacje o mechanizmach sprawowania władzy, o strukturze społecznych wpływów i mechanizmach kształtowania politycznego dyskursu; aspiracje ekspertów uznających, że dysponują wiedzą poznawczo uprzywilejowaną, gdy zostaną skonfrontowane z przekonaniami opinii publicznej, mogą stanowić przesłankę «upowszechnienia» czy «popularyzacji» tej wiedzy, ale mogą też być podstawą dla rekonstrukcji struktury grupowych interesów; strukturalne zróżnicowanie poglądów opinii publicznej w jednych sprawach łączy się zwykle ze zróżnicowaniem tych poglądów w innych sprawach i pozwala na rekonstrukcję szerszych reprezentacji społecznego świata"5.

Wszelkie zakazy i ograniczenia spożywania i sprzedaży alkoholu nie sprawdziły się do tej pory w żadnym kraju, czego przykładem może być wprowadzenie prohibicji w USA, która przyczyniła się do rozkwitu „podziemia” związanego z nielegalną produkcją i dystrybucją napojów alkoholowych i do wzrostu przestępczości zorganizowanej. Wprowadzona w Polsce słynna „godzina trzynasta” była impulsem do zwiększenia aktywności ludzi pijących alkohol codziennie, którzy ustawiali się w długich kolejkach, aby już w pierwszych minutach po otwarciu punktów sprzedaży alkoholu zaopatrzyć się w „upragniony towar”, zaś w porze zakazu dokonywali zakupów „na melinach” lub u producentów znanego wszystkim bimbru. W dziejach Polski znane są także przypadki świadomego przyzwalania władz na upijanie się obywateli oraz celowe rozpijanie społeczeństwa przez zaborców i okupantów, aby pozyskiwać podległość ludzi uzależnionych od alkoholu lub zachęcać ich do współpracy i zdrady swoich

$4 \quad$ K. W. Frieske, Pochwała zdrowego rozsądku: Problemy społeczne w społecznej świadomości, [w:] Alkohol a społeczeństwo. Postawy i zachowania Polaków wobec alkoholu i problemów alkoholowych (Alkohol a zdrowie, 30) red. J. Sierosławski, Warszawa 2004, s. 107.

5 Tamże, s. 109. 
rodaków, którzy działali przeciwko wrogim narodowi siłom. Alkohol może być doskonałym narzędziem manipulacji, środkiem płatniczym, bronią w posiadaniu przedstawicieli władzy i źródłem zniewolenia osób, które „zapijanie” trudnych spraw i przykrych emocji traktują jako sposób rozwiązywania problemów.

Aktualna sytuacja społeczno-ekonomiczna w wielu krajach (do których również zalicza się Polska), stanowi źródło rozmaitych kryzysów związanych z bezrobociem, migracjami i demograficznym starzeniem się społeczeństw. Ludzie pozbawieni możliwości zaplanowania godnego życia dla siebie, a w przyszłości dla swojego potomstwa, którzy nie potrafią znaleźć wyjścia z kryzysu sytuacyjnego, przyjmują postawę wyczekiwania „na lepsze czasy”, stopniowo wycofując się $\mathrm{z}$ aktywności i popadając w wyuczoną bezradność. Taki stan sprzyja wielu autodestrukcyjnym zachowaniom, m.in. uzależnieniu od środków psychoaktywnych, z których najbardziej dostępny jest alkohol pomagający szybko zapomnieć o problemach i „znieczulający” ból egzystencjalny.

Wprawdzie społeczeństwo uznaje alkoholizm za poważny problem zdrowotny, jednak rzadko zdarza się, aby uroczystości rodzinne i spotkania okolicznościowe odbywały się bez alkoholu. Modne spotkania przy grillu nie mogą odbyć się bez piwa, które pojawia się we wszystkich reklamach ukazujących piękno przyrody, imprezy plenerowe czy męską siłę i witalność. Doświadczenia młodych ludzi z alkoholem rozpoczynają się najczęściej od picia piwa. Jest to napój, który po spożyciu nie powoduje przykrych objawów zatrucia i ma przyjemny, orzeźwiający smak, zwłaszcza po schłodzeniu w lodówce. Ma cenę przystępną dla kieszeni studenta, którego zachęcają do picia piwa promocje („piątki dla studenta”, „piwo gratis dla pań”, wakacyjne imprezy w miejscowościach wypoczynkowych z „ulgą dla studenta”).

\section{Funkcjonowanie rodziny żyjącej z osoba uzależniona}

Rodzina zmagająca się z uzależnieniem od alkoholu jednego z jej członków najczęściej nie podejmuje żadnych działań w kierunku rozwiązania problemu. Głównym powodem jest brak wiedzy na temat współuzależnienia wszystkich osób żyjących pod wspólnym dachem z osobą uzależnioną. Współmałżonek/ partner oraz dzieci uzależnionego członka rodziny odczuwają wstyd z powodu obwiniania ich za ten stan rzeczy przez samego pijącego, co blokuje, a nawet paraliżuje działanie w kierunku rozwiązania problemu. Okresy picia i towarzyszących im awantur, aktów agresji i przemocy, przeplatane „miodowymi miesiącami” utwierdzają wszystkich domowników w przekonaniu, że kiedyś nastąpi koniec nałogu i wszystko „jakoś się ułoży”. Piciu problemowemu za- 
przecza nie tylko pijący, ale także jego najbliżsi, gdy dojdzie do ujawnienia tego faktu i potwierdzenia go przez osoby spoza rodziny. Pomimo cierpień i strat spowodowanych brakiem troski pijącego o członków rodziny i jego nieobecności w organizacji codziennego życia, współmałżonek/partner i dzieci nakładają „maski”, twierdząc, że problemu nie ma.

Żona alkoholika nie może liczyć na oparcie w wychowaniu dzieci, ponieważ ma „raczej jedno duże dziecko więcej niż męża czy ojca. Duże dziecko, oporne na wychowanie i dostarczające najwięcej kłopotów, ogromu złości i rozpaczy"'. Stwarza to sytuację ważnych braków: stabilności, porządku życiowego, możliwości przewidywania zdarzeń, planowania i kontroli nad własnym życiem. Pojawiają się także specyficzne naciski: by coś nareszcie z tym zrobić (jedni radzą rozwód, inni wykazanie łagodności i wyrozumiałości); należy za wszelką cenę „trzymać twarz” (nikt nie może dowiedzieć się, że jest bardzo źle); presja alkoholika („piję przez ciebie”); presja dzieci („nie może być tak dłużej”); presja teściowej („bądź lepszą żoną”). Braki i naciski wyzwalają określone uczucia i prowokują określone zachowania (tabela 2.).

Tabela 2. Uczucia i zachowania współmałżonka osoby uzależnionej związane z sytuacją braków i nacisków

\begin{tabular}{|c|l|l|}
\hline Lp. & Uczucia/emocje & \multicolumn{1}{c|}{ Reakcje } \\
\hline 1 & wstyd & $\begin{array}{l}\text { - izolacja społeczna } \\
\text { - system kłamstw i zatajania } \\
\text { - okazywanie alkoholikowi złości }\end{array}$ \\
\hline 2 & bezradność & $\begin{array}{l}\text { - zwiększenie nacisku } \\
\text { - wzrost kontroli } \\
\text { - ograniczanie wolności: odbieranie wypłaty alkoholika } \\
\text { - chowanie i wylewanie alkoholu } \\
\text { - szantażowanie rozwodem } \\
\text { - kontrolowanie miejsca pobytu } \\
\text { - wyciąganie męża z knajpy } \\
\text { - zamykanie męża w domu } \\
\text { - chowanie ubrania i butów } \\
\text { - przynoszenie wódki, aby „wypił w domu, jeśli musi” }\end{array}$ \\
\hline 3 & niepewność & $\begin{array}{l}\text { - próba zaprowadzenia większego porządku przez wzmocnie- } \\
\text { nie kontroli } \\
\text { - ucieczka w sensie fizycznym: wyjście z domu na jakiś czas, } \\
\text { wyprowadzenie się } \\
\text { - ucieczka w sensie symbolicznym: w chorobę, środki } \\
\text { psychoaktywne, leki, alkohol }\end{array}$ \\
\hline
\end{tabular}

$6 \quad$ W. Sztander, Poza kontrola, dz. cyt., s. 32. 


\begin{tabular}{|c|l|l|}
\hline Lp. & Uczucia/emocje & \multicolumn{1}{c|}{ Reakcje } \\
\hline 4 & lęk/strach & $\begin{array}{l}\text { - podporządkowanie w obawie przed pobiciem, utratą zdro- } \\
\text { wia i życia, zabraniem dziecka, samobójstwem alkoholika } \\
\text { - klimat urazy: milczenie z równoczesnym napięciem grożą- } \\
\text { cym wybuchem agresji } \\
\text { - krzyk i płacz } \\
\text { - „huśtawka między urazą a poczuciem winy” (oskarżanie al- } \\
\text { koholika albo siebie) }\end{array}$ \\
\hline 5 & poczucie winy & $\begin{array}{l}\text { - przyjmowanie odpowiedzialności za picie alkoholika } \\
\text { - udowadnianie swojej niewinności i obwinianie innych } \\
\text { - psychiczne znęcanie się nad sobą } \\
\text { - rezygnacja z własnych potrzeb i dbałości o siebie } \\
\text { - podporządkowanie się innym }\end{array}$ \\
\hline 6 & $\begin{array}{l}\text { gniew, złość, } \\
\text { agresja }\end{array}$ & $\begin{array}{l}\text { - wyrażanie ,zakamuflowanej” agresji (dążenie do kompro- } \\
\text { mitacji alkoholika) } \\
\text { - stwarzanie sytuacji prowadzących do upokorzenia alko- } \\
\text { holika } \\
- \text { deprecjonowanie zachowań pozytywnych } \\
- \text { przypisywanie złych motywów wszystkim czynom alko- } \\
\text { holika } \\
- \text { okazywanie satysfakcji z upokorzenia alkoholika }\end{array}$ \\
\hline
\end{tabular}

Źródło: W. Sztander, Poza kontrolą, dz. cyt., s. 32-38. Opracowanie własne.

Dzieci dorastające w rodzinach z problemem alkoholowym nie mają wzorców ról kształtujących zdrową osobowość. Uczą się, jak postępować, żeby przetrwać w chaotycznej rodzinie, przyjmując stereotypowe role, do których należą:

- bohater rodzinny (zazwyczaj najstarsze dziecko, które czuje się odpowiedzialne za cierpienie rodziny, „mały dorosły”, opiekun rodziców i rodzeństwa);

- kozioł ofiarny (zaburzone dziecko, które ma niskie poczucie własnej wartości i próbuje poprawić swój wizerunek zachowaniami buntowniczymi);

- dziecko zagubione (wykonuje wszystkie polecenia, nie okazuje uczuć, nie próbuje zwrócić na siebie uwagi, nie udziela się społecznie, jest samotnikiem);

- rodzinna maskotka (z zasady najmłodsze dziecko, uspokaja i pociesza wszystkich, może odwracać uwagę od problemów wesołością, może uciekać w chorobę, oczekując troskliwej opieki).

Dzieci przestrzegają również narzuconych przez rodziców reguł rodzinnych, które przedstawiono w tabeli 3. 
Tabela 3. Reguły rodzinne w rodzinach alkoholików

\begin{tabular}{|l|l|}
\hline \multicolumn{1}{|c|}{ Reguła } & \multicolumn{1}{c|}{ Charakterystyka } \\
\hline $\begin{array}{l}\text { Nie mów, a nie będziesz } \\
\text { miał problemów. }\end{array}$ & $\begin{array}{l}\text { Rodzice zaprzeczają problemowi alkoholizmu i sygnalizu- } \\
\text { ją zakaz: „nie ma problemu, dlatego nie rozmawiaj z nikim } \\
\text { o tym, bo będą się działy niedobre rzeczy”. }\end{array}$ \\
\hline Nie ufaj. & $\begin{array}{l}\text { Nie można ufać rodzicom, że dadzą wsparcie i zaspoko- } \\
\text { ją potrzeby. }\end{array}$ \\
\hline Nie czuj. & Aby nie cierpieć, należy zaprzeczać uczuciom. \\
\hline $\begin{array}{l}\text { Nie zmieniaj swoich } \\
\text { zachowań. }\end{array}$ & Nie wolno zmieniać ról, aby nie burzyć systemu. \\
\hline Nie wiń za nic uzależnienia. & $\begin{array}{l}\text { Nieszczéściem pijącego kieruje zły los, za który są odpo- } \\
\text { wiedzialni inni ludzie. }\end{array}$ \\
\hline $\begin{array}{l}\text { Zachowuj się tak, jak ja } \\
\text { chcę. }\end{array}$ & $\begin{array}{l}\text { Wszyscy muszą zachowywać się zgodnie z życzeniem } \\
\text { alkoholika. }\end{array}$ \\
\hline $\begin{array}{l}\text { Bądź lepszy i bardziej } \\
\text { odpowiedzialny. }\end{array}$ & $\begin{array}{l}\text { Winę za upadek i niepowodzenia alkoholika ponoszą oso- } \\
\text { by bliskie. }\end{array}$ \\
\hline Nie miej żadnych radości. & $\begin{array}{l}\text { Jedyną radością jest picie, członkowie rodziny są zmęcze- } \\
\text { ni pracą nad utrzymaniem systemu w równowadze i nic } \\
\text { ich nie cieszy. }\end{array}$ \\
\hline
\end{tabular}

Źródło: R. K.James, B. E.Gilliland, Strategie interwencji kryzysowej, dz. cyt., s. 444-446.

Największą tragedią dzieci dorastających w rodzinie z problemem alkoholowym jest nieuświadomione przenoszenie przez nie jako dorosłe dzieci alkoholików (DDA) pełnionych ról do dorosłego życia. Bohaterowie chcą panować nad otoczeniem i mieć nad wszystkim kontrolę, nie umieją cieszyć się życiem. Zagubione dziecko nie potrafi dokonywać wyborów, ponieważ nigdy nie wymagano od niego podejmowania decyzji, to osoba samotna, przygnębiona i społecznie odizolowana. Rodzinne maskotki to osoby miłe, próbujące wszystkim sprawić przyjemność, umiejące znakomicie odwracać uwagę od problemów związanych z nadużywaniem alkoholu przez członka rodziny. Kozioł ofiarny jest osobą, która nie potrafi stanąć we własnej obronie, daje się wykorzystywać i nadużywać, zaś jej niskie wyobrażenie o sobie skłania ją do poprawy swego samopoczucia za pomocą środków psychoaktywnych ${ }^{7}$.

DDA mają problemy związane z: ufaniem innym, zależnością, kontrolą, identyfikacją i wyrażaniem uczuć. Doświadczają paraliżującego lęku i strachu przed porzuceniem. Trzymają się kurczowo partnera albo nie potrafią tworzyć trwałych związków. Mają często nieuzasadnione wahania nastroju. U obu płci

7 R. K. James, B. E. Gilliland, Strategie interwencji kryzysowej, dz. cyt., s. 449-450. 
DDA występuje ciągłe poczucie winy. Kobiety wykazują szczególną wrażliwość na krytykę (także domniemaną). Mężczyźni bardzo szybko wpadają w gniew, gdy tracą kontrolę nad emocjami. Opracowano listę dwunastu problemów, z którymi DDA borykają się przez całe życie:

- Zgadują, co to znaczy być „normalnym”.

- Są mistrzami w odkładaniu wszystkiego na później.

- Kłamią, kiedy łatwiej byłoby powiedzieć prawdę.

- Bezwzględnie osądzają samych siebie.

- Traktują siebie zbyt poważnie i mają mało radości w życiu.

- Mają problemy w związkach intymnych.

- Impulsywnie reagują na zmiany, nad którymi nie mają kontroli.

- Nieustannie poszukują aprobaty i afirmacji.

- Czują, że różnią się od innych ludzi.

- Są nadmiernie odpowiedzialne albo nieodpowiedzialne.

- Są lojalne, nawet jeśli lojalność nie jest niczym usprawiedliwiona.

- Są impulsywne ${ }^{8}$.

\section{Ułałwianie i współuzależnienie}

Zjawisko ułatwiania i współuzależnienia wiąże się z doświadczeniami osób, które zetknęły się z problemem alkoholowym w swoim najbliższym otoczeniu. Ułatwianie polega na działaniu osób w jakiś sposób związanych z uzależnionym lub mających osobiste doświadczenia $\mathrm{z}$ nałogiem $\mathrm{z}$ okresu dzieciństwa (współmałżonek, przyjaciel, pracodawca, osoba wspierająca finansowo pijącego), przekonanych, że wyświadczają pijącemu przysługę poprzez: wykonywanie za niego pracy, krycie niedostatków jego pracy, akceptowanie wymówek lub godzenie się na specjalne układy, przymykanie oka na częste nieobecności i spóźnienia, niezauważanie dowodów nadużywania alkoholu. Współuzależnienie oznacza występowanie szeregu ściśle określonych objawów u członków rodziny osoby uzależnionej. Zjawisko dotyczy najczęściej współmałżonka, rodzica lub dziecka. Jean Kinney i Gwen Leaton wyróżniają pięć kryteriów pozwalających na rozpoznanie współuzależnienia:

- Własna samoocena zależy od umiejętności kontrolowania siebie w sytuacji zagrożenia.

- Branie odpowiedzialności za zaspokojenie potrzeb innych kosztem własnych potrzeb.

- Problemy z wyznaczaniem granicy między zbliżeniem a zachowaniem dystansu i związany z tym lęk.

8 Tamże, s. $450-451$. 
- Skłonność do związków z osobami o zaburzonej osobowości, uzależnionymi, współuzależnionymi.

- Spełnianie trzech lub więcej następujących warunków: silne mechanizmy zaprzeczania, tłumienie uczuć, depresja, nadmierna czujność, kompulsywność, lęk, nadużywanie środków zmieniających świadomość, aktualne/w przeszłości doświadczanie przemocy fizycznej lub seksualnej, choroby somatyczne związane ze stresem, pozostawanie w ścisłym związku z osobą uzależnioną przez okres co najmniej 2 lat, bez próby poszukiwania pomocy ${ }^{9}$.

Alkoholizm jest chorobą, dlatego osobę uzależnioną powinno uznawać się za osobę chorą, wymagającą leczenia, a nie traktować jak dziecko. Obwinianie uzależnionego za problem lub nadmierne chronienie go nie ma racjonalnego uzasadnienia, ponieważ nie prowadzi do zmiany, natomiast stanowi poważne zagrożenie dla zdrowia i życia pijącego i członków jego rodziny. Jedyną skuteczną formą terapii jest zaprzestanie spożywania alkoholu i utrzymywanie trzeźwości do końca życia. Osoba uzależniona może podjąć decyzję o zaprzestaniu picia tylko wtedy, gdy uzna, że sama ponosi odpowiedzialność za skutki utraty kontroli nad swoim piciem, powodując wiele strat osobistych i całej rodziny, narażając wszystkich na cierpienia i krzywdę. Duże znaczenie w motywowaniu pijącego do zachowania trzeźwości ma krótka interwencja rodzinna podczas spotkania w gronie osób znaczących dla uzależnionego. Polega ona na przyznaniu się osoby uzależnionej do tego, że ma problem, za który nie są odpowiedzialne osoby trzecie, a w związku z tym to osoba uzależniona ma obowiązek podjąć decyzję o zaprzestaniu picia. Podczas takiego spotkania należy zapewnić uzależnionego, że wszyscy martwią się o jego zdrowie, ponieważ alkoholizm jest chorobą śmiertelną. Jeśli alkoholik zobowiąże się do zmiany, powinien uzyskać wsparcie bliskich osób w trudnych chwilach trzeźwienia, gdy występują objawy abstynenckie związane z głodem alkoholowym. Istotę i przyczyny problemu powinny także uświadomić sobie osoby współuzależnione, bo tylko wtedy będą zdolne do zdjęcia z siebie odpowiedzialności i poczucia winy za nadużywanie alkoholu przez członka rodziny, a tym samym będą w stanie podjąć trud wspierania alkoholika w procesie zdrowienia.

\section{Materiał i metoda}

Istotę współuzależnienia można wyjaśnić na przykładzie studium przypadku ukazującego próby usprawiedliwiania przez żonę zachowań męża nadużywającego alkoholu. Jest to najczęściej występujący przykład współuzależnie-

\footnotetext{
9 J. Kinney, G. Leaton, Zrozumieć alkohol, Warszawa, 1996, s. 153-154.
} 
nia. Innym przykładem jest matka żyjąca pod jednym dachem z dorosłym synem uzależnionym od alkoholu, który albo nie założył rodziny, albo z powodu problemu $\mathrm{z}$ alkoholem i stosowania przemocy musiał opuścić żonę i dzieci na mocy wyroku sądu lub w następstwie eksmisji. Niestety, coraz częściej zdarzają się także przypadki kobiet nadużywających alkoholu, które piją alkohol w ciąży lub sprawują opiekę nad dziećmi, będąc czasem jedynym ich opiekunem prawnym.

W celu uzasadnienia użycia w tytule opracowania pojęcia „pułapka współuzależnienia” przedstawiona zostanie analiza jakościowa przypadków rodzin z problemem alkoholowym. Źródłami pozyskania informacji o rodzinach były dwa wywiady swobodne z osobami zgłaszającymi się do Terenowego Komitetu Ochrony Praw Dziecka (TKOPD) w mieście W. w sprawie interwencji dotyczącej sprawowania opieki nad dziećmi oraz jeden wywiad z córką, której matka mieszka z synem uzależnionym od alkoholu. Wywiady przeprowadziła autorka opracowania w ramach pełnienia funkcji w strukturze TKOPD i Miejskiego Zespołu Interdyscyplinarnego do Spraw Przemocy w Rodzinie (MZI).

\section{Studium przypadku}

Przypadek pani A. (I. 47), żona alkoholika niepełnosprawnego intelektualnie w stopniu lekkim, matka trojga dzieci (syn I. 16, córka I. 12, syn I. 7). Przypadek zgłoszony do TKOPD

Pani A. pochodzi z rodziny inteligenckiej. Podczas nauki w szkole zawodowej w wieku 17 lat zakochała się w starszym od siebie uczniu, z którym zaszła w ciążę i z tego powodu nie ukończyła szkoły. Wówczas rodzice nakazali jej opuszczenie domu, ponieważ „przyniosła rodzinie wstyd” i zerwali z nią kontakty. Pani A. urodziła syna i zamieszkała u ojca dziecka, który, jak się okazało, miał problemy z alkoholem. Z powodu doświadczania przemocy pani A. wyprowadziła się z dzieckiem do lokalu komunalnego przyznanego przez urząd miasta. Po kilku latach poznała obecnego męża, z którym wzięła ślub kościelny. Rodzina męża zataiła przed panią A. fakt jego niepełnosprawności intelektualnej, o czym pani A. dowiedziała się dopiero po ślubie od znajomych tej rodziny. Dowiedziała się, że mąż uczęszczał do szkoły specjalnej, ale jej nie ukończył, nie miał też żadnego wyuczonego zawodu, zaś z tytułu orzeczonej niepełnosprawności otrzymał pracę w zakładzie pracy chronionej jako portier. Początkowo pani A. nie zameldowała męża w swoim mieszkaniu, uczyniła to dopiero po urodzeniu córki. Do czasu zameldowania mąż ukrywał jeszcze jeden problem - uzależnienie od alkoholu. Gdy został zameldowany, zaczął nadużywać alkoholu i źle traktować żonę. 
Po 5 latach pani A. urodziła syna. Mąż stracił zatrudnienie z powodu picia alkoholu w miejscu pracy. Kiedy syn osiągnął wiek przedszkolny, pani A. podjęła pracę jako sprzątaczka. Jej mąż z powodu braku pracy otrzymywał tylko rentę socjalną, której większą część przepijał. Podczas nieobecności żony i dzieci dokonywał zakupu taniego wina, które pił w samotności, zamykając się w pokoju. Kiedy żona wracała z pracy, zastawała męża śpiącego. Wieczorem mąż się budził i żądał, aby dzieci razem z nim oglądały telewizję albo słuchały jego skarg na brak zrozumienia przez ich matkę. Zaczął także częstować alkoholem starszego syna pani A., który miał wtedy 15 lat. Pani A. zgłosiła się do Terenowego Komitetu Ochrony Praw Dziecka w celu uzyskania pomocy w związku z awanturami, zakłócaniem dzieciom spokoju i utrudnianiem im przez ojca przygotowania się do zajęć szkolnych. Opowiedziała także o demoralizacji starszego syna, który zaczął wagarować i z powodu niesklasyfikowania został skreślony z listy uczniów.

Pani A. została poinformowana, że z uwagi na problemowe picie alkoholu przez jej męża wskazane jest podjęcie terapii odwykowej, a w kwestii relacji $\mathrm{z}$ dziećmi należy poinformować go o konieczności zapewnienia im możliwości realizacji obowiązku szkolnego i zaniechania prób wykorzystywania dzieci do roli mediatorów w relacjach pomiędzy rodzicami. Pani A. skarżyła się również, że doświadczała różnych form przemocy ze strony męża i zamierza złożyć pozew do sądu o separację i rozdzielność majątkową. Nie stać jej na poniesienie kosztów rozwodu, a ponieważ zameldowała męża w lokalu, który otrzymała, zanim zawarła związek małżeński, nie ma możliwości uzyskania kolejnego mieszkania.

Mąż pani A. stwierdził, że nie pije dużo alkoholu, ale zdarzyło mu się jeden raz uderzyć żonę, która „niepotrzebnie wezwała policję, bo tylko miała siniaki”. Powiedział, że kocha żonę i że byłby dla niej dobry, gdyby ją ktoś namówił, żeby „chciała razem z nim spać w jednym łóżku, bo przecież mąż i żona, jak się kochają, to śpią razem”. Zapytany, czy częstował winem swojego pasierba, zdecydowanie zaprzeczył, natomiast powiedział, że chłopak go denerwuje, nazywając „głupim”. Rozmowa z mężem pani A. nie zmieniła jego stanowiska w kwestii zachowania wobec dzieci. Pani A. jeszcze przez pół roku wahała się, czy złożyć wniosek o przymusowe leczenie odwykowe męża, ale z uwagi na jego coraz bardziej uciążliwe zachowanie i uchylanie się od obowiązku ponoszenia kosztów utrzymania, podjęła taką decyzję. Mąż zachowywał spokój i trzeźwość przez okres dwóch miesięcy, rekompensując sobie brak alkoholu w organizmie konsumowaniem dużych ilości słodyczy, które popijał napojami gazowanymi. Po tym okresie zaczął popijać piwo i wszczynać awantury. Pani A. nie informowała o tym sądu, ponieważ stwierdziła, że mąż się nie podporządkuje żadnym nakazom, „bo jest ograniczony umysłowo i niczego nie rozumie”. MOPS przydzielił rodzinie asystenta rodzinnego, ponieważ z powodu niewy- 
dolności opiekuńczej rodziców i braku wzorców wychowawczych córka pani A. zaczęła wagarować, eksperymentować $\mathrm{z}$ alkoholem i papierosami, w wieku 17 lat nie wracała do domu na noc, opuszczała szkołę, zaś młodszy syn, 14-latek, został przywieziony do domu przez policję, ponieważ był pod wpływem alkoholu. Pani A. zaczęła podejmować różne dodatkowe prace, ponieważ zaciągała kredyty i pożyczki na pokrywanie kosztów utrzymania rodziny i była ciągle nieobecna w mieszkaniu. $Z$ tego powodu straciła nadzór nad dziećmi oraz nie miała czasu na prowadzenie domu i utrzymywanie w nim porządku.

Przypadek pani B. (I. 88), wdowa po oficerze Wojska Polskiego, zamieszkała wspólnie z synem alkoholikiem (l. 63). Przypadek zgłoszony do przedstawiciela MzI

Pani B. była żoną wysokiej rangi oficera Wojska Polskiego, która prowadziła dostatnie życie dzięki wysokiej pozycji społecznej i dobremu uposażeniu finansowemu męża. Miała dwoje dzieci - córkę i syna. Córka ukończyła studia wyższe i założyła swoją rodzinę. Syn już w dzieciństwie sprawiał problemy wychowawcze. Z powodu nadpobudliwości psychoruchowej miał kłopoty z dyscypliną szkolną, nie chciał się uczyć, wagarował, wdawał się w bójki i awantury. Zaczął wcześnie eksperymentować $\mathrm{z}$ alkoholem, wynosił z domu różne przedmioty i sprzedawał je, aby pozyskać środki na zakup alkoholu, zaczął kraść i zawierać różne transakcje handlowe w kraju i za granicą, oparte na oszustwach i wyłudzeniach. Wszystkie jego nadużycia i oszustwa kryła matka, nie ujawniając mężowi wielu sytuacji związanych z zadośćuczynianiem osobom pokrzywdzonym przez syna. Pomimo inwestowanych środków na opłacanie korepetycji i terapii psychologicznych syn ukończył tylko 7 klas szkoły podstawowej. Ponieważ ojciec z racji swojej pozycji zawodowej i społecznej nie mógł pogodzić się z zachowaniem syna, nakazał mu opuścić dom i usamodzielnić się. Syn wyjechał do pracy w kopalni, gdzie pracował przez trzy miesiące, zaś po tym okresie z powodu urazu kręgosłupa przeszedł na rentę i powrócił do poprzedniego „pasożytniczego” sposobu życia. Wchodził trzykrotnie w związki z kobietami (jeden raz ożenił się, a dwa razy żył w konkubinacie), został ojcem trójki dzieci. Zawsze potrafił wychodzić z opresji dzięki manipulacjom i wyłudzaniu środków finansowych od ludzi, których potrafił przekonać do różnych inwestycji w rzekomo prowadzonych przez siebie firmach lub agencjach. Zanim ofiary jego malwersacji zdążyły zgłosić przestępstwa, syn pani B. przenosił się do innego miasta albo za granicę (Ukraina, Rosja, Niemcy). W swoich działaniach był przekonujący, dlatego ludzie mu ufali. Kobiety, z którymi się wiązał, też były przez niego oszukiwane i okradane. 
Po śmierci ojca zamieszkał z matką, która przepisała prawo własności lokalu na syna, z zastrzeżeniem dla siebie prawa dożywotniego zamieszkania. Wysoka emerytura, którą dysponowała pani B., okazała się doskonałym sposobem na „bezpieczne picie” dla jej syna, który nie ponosił żadnych kosztów utrzymania, nie dokonywał opłat, ponieważ matka twierdziła, że chce mu zrekompensować surowe traktowanie w dzieciństwie przez ojca, który nie wykazywał zrozumienia dla słabości syna. Pani B. uznała, że sama też ponosi odpowiedzialność za to, że syn jest samotny i nie potrafi żyć bez alkoholu. Z uwagi na podeszły wiek i problemy zdrowotne zatrudniła opiekunkę, która przyrządzała posiłki i wykonywała wszystkie prace domowe, także na rzecz jej syna. Obawiając się o swoje środki finansowe, pani B. upoważniła swoją córkę do wyłącznego pobierania środków z konta bankowego, ponieważ wszystkie pieniądze pozostawione w domu „znikały”. Jednak w krótkim czasie syn zaczął szantażować matkę twierdząc, że musi mu dawać pieniądze na leki, rehabilitację i drogie badania. Wszystkie zdobyte w ten sposób pieniądze przeznaczał na alkohol pity w towarzystwie kolegów i kobiet uprawiających prostytucję.

Głośne awantury doprowadziły do tego, że sąsiedzi, którzy słyszeli wyzwiska i przekleństwa kierowane przez syna do pani B., wezwali policję. Po interwencji i przeprowadzeniu wywiadu środowiskowego przez dzielnicowego policja złożyła doniesienie do prokuratury o stosowanie przez syna przemocy wobec matki. Podczas kolejnej awantury syn pani B. został zatrzymany i przewieziony do izby wytrzeźwień, po której opuszczeniu uspokoił się i poprosił matkę, aby dała mu pieniądze na pokrycie kosztu pobytu. Pani B. bez oporu spełniła prośbę syna. W mieszkaniu pojawił się prokurator w celu przesłuchania pani B. i zebrania dowodów niezbędnych do wniesienia pozwu do sądu o popełnienie przestępstwa $\mathrm{z}$ art. $207 \mathrm{Kk}$ (znęcanie się). Pani B. prosiła o wycofanie zarzutu twierdząc, że syn jej nie krzywdzi, tylko zdarza mu się nadużywać alkoholu. Kolejne awantury sprawiły, że policja złożyła wniosek do sądu o przymusową terapię odwykową syna pani B., ten jednak nie zgłosił się na wezwanie do placówki terapii odwykowej w wyznaczonym terminie.

Następnym krokiem, który poczynił syn pani B., było pozbawienie matki kontaktu z córką. Oświadczył on siostrze, że zakazuje jej odwiedzać matkę, bo to on jest właścicielem mieszkania i ma prawo decydować o tym, kto może do niego wejść. Stosował groźby karalne, strasząc siostrę, że jeśli naruszy jego zakaz, to ją pobije. Zażyczył sobie, żeby siostra przekazywała matce pieniądze poza jej miejscem zamieszkania, przez opiekunkę. Powiadomiony o tym dzielnicowy stwierdził, że zgodnie z prawem właściciel może zabronić wejścia do swojego mieszkania osobom przez niego niepożądanym. Gdyby matka nie wycofała sprawy o znęcanie, sytuacja wyglądałaby inaczej. Kontakty matki z córką odbywały się wyłącznie drogą telefoniczną i polegały na prośbach o przekazywanie 
kwot pieniężnych (5-7 tys. zł miesięcznie), które znacznie przekraczały jej potrzeby. Córka podejrzewała, że jej brat wyłudza od matki pieniądze, ponieważ zaciąga różne pożyczki, które przeznacza na zakup alkoholu, zaś matka ponosi koszty zadłużenia, aby uniknąć egzekucji komorniczej.

Kiedy opiekunka pani B. poinformowała jej córkę, że po wolnym weekendzie zastaje podopieczną zaniedbaną higienicznie, odwodnioną i wygłodzoną. Ponieważ pani B. jest osobą całkowicie wymagającą opieki, córka zgłosiła problem do pracownika socjalnego, który podczas wizyty w mieszkaniu pani B. uzyskał od niej informację, że podczas nieobecności opiekunki syn troszczy się o nią bez zastrzeżeń. Syn pani B., bezkarny dzięki ochronie jego osoby przez matkę, posunął się jeszcze dalej i zaczął stosować wobec opiekunki groźby karalne. Ta oświadczyła, że rezygnuje z pracy w obawie o swoje bezpieczeństwo, jednak na prośbę podopiecznej nie zgłosiła gróźb na policję. Syn pani B. stwierdził, że sam zaopiekuje się matką przy pomocy kobiety, z którą zamieszkał, i swojego sąsiada, ponieważ nie życzy sobie w swoim domu żadnych obcych osób. Zażądał także, żeby siostra przychodziła do matki raz w tygodniu w celu przekazania jej pieniędzy w obecności opiekunki z MOPS-u. Opiekunka przychodziła pięć razy w tygodniu na godzinę w celu wykonania czynności higienicznych u pani B. Matka pytana przez córkę, czy ma zapewnioną właściwą opiekę ze strony syna, odpowiadała, że nie ma zastrzeżeń. Pewnego dnia sąsiadka pani B. usłyszała ciche pukanie do drzwi, a następnie głos przypominający płacz dziecka. Kiedy otworzyła drzwi, ujrzała przerażający widok. Pani B. klęczała przy drzwiach i prosiła o szklankę wody i coś do jedzenia, ponieważ jest głodna. Boi się syna i prosi o szybką pomoc, zanim syn wróci ze sklepu. Sąsiadka spełniła prośbę, chciała też zadzwonić do MOPS-u lub na policję, ale pani B. prosiła jedynie o telefon do opiekunki, żeby doprowadziła ją do porządku, bo czułaby się upokorzona, gdyby ktoś obcy zastał ją brudną i zanieczyszczoną. Opiekunka niezwłocznie przybyła na miejsce, a po wykonaniu czynności higienicznych i uprzątnięciu pokoju pani B. zadzwoniła do córki. Córka jeszcze tego samego dnia znalazła placówkę pielęgnacyjno-opiekuńczą dla osób starszych (niepubliczny DPS), gdzie od razu udało się jej umieścić matkę. Było to możliwe tylko dzięki posiadanym przez panią B. środkom pochodzącym z wysokiej emerytury. Następnego dnia po opuszczeniu przez panią B. mieszkania jej syn wymienił zamki w drzwiach, twierdząc, że nie życzy sobie niczyich wizyt. Ponieważ pani B. opuściła dom jedynie w koszuli nocnej i szlafroku, córka nie mając dostępu do jej rzeczy osobistych ani ubrań, była zmuszona do ich zakupu. Syn pani B. zażądał od matki przekazywania środków pieniężnych na pokrywanie opłat eksploatacyjnych mieszkania, pomimo że matka przebywając w placówce ponosiła koszt utrzymania w wysokości ponad 3 tys. zł. Żądanie syna nie mogło jednak zostać spełnio- 
ne, ponieważ pani B. nie dysponowała żadną gotówką, a wszystkie formalności związane z pokrywaniem kosztów jej pobytu i zaspokojeniem innych potrzeb załatwiała córka. Pracownicy placówki zostali poinformowani o postawie syna, który doprowadził matkę do stanu zagrażającego życiu, dlatego nie pozwalali mu odwiedzać matki, gdy był pod wpływem alkoholu. Jednak zgodnie $z$ jej życzeniem nie mogli całkowicie zabronić mu wizyt. Odbywał je pod rygorem wezwania policji, gdyby zakłócał spokój lub zachowywał się w sposób narażający matkę na stres.

Przypadek pani C. (I. 43), rozwiedziona, uzależniona od alkoholu, sprawująca opiekę nad synem (l. 8), kłórego ojciec opuścił zakład karny, matka dorosłej córki (I. 20) z pierwszego związku. Przypadek zgłoszony do TKOPD

Pani C. jest osobą pracującą, mieszka z córką i synem. Jej konkubent (S.) został skazany na karę więzienia za kradzieże. Pochodził z rodziny dysfunkcyjnej, dotkniętej problemem alkoholowym i przemocą. Ze względu na nadpobudliwość i sprawianie problemów wychowawczych S. był często dotkliwie karany przez swojego ojca, czego skutkiem była decyzja sądu rodzinnego o pozbawieniu rodziny prawa do opieki i przekazaniu S. do ośrodka szkolno-wychowawczego. Po opuszczeniu placówki S. związał się z panią C. i zamieszkał wspólnie z nią i jej córką. Z nieformalnego związku urodził się syn. S. przejął główne obowiązki opiekuńcze nad synem, ponieważ nie mógł znaleźć zatrudnienia, podczas gdy matka chłopca pracowała w systemie trzyzmianowym. Pan S. pragnął, jak podał, okazywać synowi miłość i zapewnić mu troskliwą opiekę, jakiej sam nie doświadczył w swoim domu rodzinnym. Pani C. była osobą niewydolną, jeśli chodzi o sprawowanie opieki nad dzieckiem, dlatego synem opiekował się S. wspólnie ze starszą córką pani C. Z powodu niskiego wynagrodzenia pani C. i jej problemu $\mathrm{z}$ alkoholem oraz bezrobocia pana S. rodzina nie była w stanie utrzymać się na poziomie minimum socjalnego. Pani C. wyrzuciła swojego konkubenta z domu, który aby przetrwać, zaczął kraść i przynosić pieniądze, dzięki czemu uzyskiwał zgodę partnerki na kontakty z synem. Jednak żądała ona coraz większych sum pieniężnych, z których część przeznaczała na alkohol. W domu często odbywały się awantury, które kończyły się interwencją policji. Sąsiedzi poinformowali Miejski Ośrodek Pomocy Społecznej, że chłopiec przesiaduje całymi dniami na klatce schodowej i mówi przechodzącym, że jest głodny. Podczas wywiadu środowiskowego prowadzonego przez pracownika socjalnego jedna $\mathrm{z}$ sąsiadek potwierdziła ten fakt, mówiąc, że często zapraszała chłopca do siebie i częstowała go obiadem. Rodzina otrzymała dozór kuratorski z powodu zaniedbań opiekuńczych wobec syna. 
Matka chłopca zadłużyła się znacznie, dlatego aby nie stracić mieszkania, przyjęła swoją znajomą, która za możliwość zamieszkania u pani C. wraz ze swoim przyjacielem pokrywała część kosztów utrzymania. Pan S. podczas kolejnej kradzieży został zatrzymany przez policję i skazany na karę pozbawienia wolności na okres 2 lat. Po wyjściu na wolność pan S. chciał spotykać się z synem, ale pani C. uniemożliwiała mu wszelkie kontakty, strasząc go interwencją policji za każdym razem, gdy chciał wejść do jej mieszkania. Kiedy pan S. zawarł związek małżeński z inną kobietą i zamieszkał u niej w domu oraz podjął dorywczą pracę, wystąpił do sądu z wnioskiem o ustalenie kontaktów z synem. Sąd rodzinny zaopiniował wniosek pozytywnie, jednak pani C. nie zawsze respektowała decyzję sądu i awanturowała się, gdy pan S. pojawiał się, aby spotkać się z synem. Z uwagi na swą przeszłość kryminalną pan S. nie prosił policji o interwencję, aby nie być posądzonym o zakłócanie spokoju. Syn podczas jednego ze spotkań powiedział ojcu, że koleżanka matki ze swoim przyjacielem mieszkają razem z nimi i często po spożyciu alkoholu śpią w jego łóżku, a on wtedy musi spać w fotelu. „Mama też pije alkohol razem z nimi”. Wówczas pan S. wystąpił z ponownym wnioskiem do sądu o przejęcie prawa do opieki nad synem z powodu niewłaściwie sprawowanej opieki ze strony matki, która często nadużywała alkoholu i nie potrafiła zaspokoić podstawowych potrzeb dziecka, równocześnie narażając je na demoralizację. Matka początkowo zaprzeczała, że ma problem z alkoholem, ale pod groźbą utraty prawa do opieki nad synem i obowiązku alimentacyjnego w przypadku zmiany zarządzenia opiekuńczego na korzyść ojca, zobowiązała się dobrowolnie do podjęcia terapii odwykowej i poleciła swojej znajomej, aby się wyprowadziła. Pracownicy socjalni monitorujący sytuację rodziny potwierdzili korzystne zmiany w zachowaniu matki i pełne respektowanie przez nią zarządzenia sądu w sprawie kontaktów syna z ojcem. Wobec takiego obrotu sprawy matka zachowała prawo do opieki nad synem, zaś ojcu przyznano prawo do nieograniczonych kontaktów z synem oraz stałych kontaktów w miejscu zamieszkania ojca, wyznaczonych w określonych dniach wolnych od nauki szkolnej. Dzięki nadzorowi kuratora możliwy jest stały wgląd w sytuację opiekuńczo-wychowawczą dziecka.

\section{Podsumowanie i wnioski}

Jak wykazała analiza przedstawionych losów rodzin, w których przynajmniej jedna osoba ma problem $\mathrm{z}$ alkoholem, podejmowanie jakichkolwiek działań w celu poprawy sytuacji rodziny jest odraczane do momentu pojawienia się kryzysu zagrażającego jej utratą status quo. Współuzależnienie utrudnia podejmowanie skutecznych kroków naprawczych, ponieważ osoba pijąca potrafi 
skutecznie manipulować otoczeniem, dowodząc braku problemu, lub poszukuje sposobów udowodnienia winy leżącej po stronie innych członków rodziny. Ponadto dla poprawy własnego wizerunku i lepszego samopoczucia wskazuje szereg okoliczności usprawiedliwiających jej nieudane, wypełnione kryzysami życia rodzinne.

Przedstawione przypadki rodzin z problemem alkoholowym świadczą o podejmowaniu przez współuzależnionego członka rodziny działań chroniących osobę uzależnioną przed odpowiedzialnością za jej zachowanie.

W przekonaniu osoby współuzależnionej ochrona pijącego jest uzasadniona, ponieważ stanowi formę rekompensaty za trudne dzieciństwo i niepowodzenia życiowe.

Podejmowanie interwencji wobec uzależnionego członka rodziny traktowane jest przez osobę współuzależnioną jako forma kary lub zemsty, a nie jako pomoc i sposób ratowania struktury rodzinnej.

Niekwestionowanymi argumentami przemawiającymi za podjęciem interwencji wobec uzależnionego członka rodziny w przedstawionych przypadkach były groźba utraty życia przez osobę współuzależnioną i ryzyko przekazania dzieci do placówki opiekuńczo-wychowawczej na mocy decyzji sądu.

\section{Bibliografia}

Frieske K. W., Pochwała zdrowego rozsadku: problemy społeczne w społecznej świadomości, [w:] Alkohol a społeczeństwo. Postawy i zachowania Polaków wobec alkoholu i problemów alkoholowych, (Alkohol a zdrowie, 30), red. J. Sierosławski, Warszawa 2004, s. 107-112. James R. K., Gilliland B. E., Strategie interwencji kryzysowej, Warszawa, 2004, Kinney J., Leaton G., Zrozumieć alkohol, Warszawa 1996.

Seitz F. C., Medycyna behawioralna podana w sposób śmiesznie prosty, Warszawa 2000.

Sztander W., Poza kontrola, Warszawa 1997. 
A. Uniwersytet Papieski T.5. Jana Pawła II 